\title{
Dukungan Pada Lansia Dalam Menghadapi Pandemi Covid-19
}

\author{
Yekti Satriyandari ${ }^{1}$, Fitria Siswi Utami ${ }^{2}$ \\ ${ }^{1,2}$ Kebidanan, Fakultas Ilmu Kesehatan Universitas 'Aisyiyah Yogyakarta, Jalan Ring Road Barat No. 63 \\ Nogotirto, Gamping, Sleman, Yogyakarta, 55292, Indonesia \\ 1yektisatriyandari@unisayogya.ac.id* \\ *corresponding author \\ Tanggal Submisi: 30 April 2021, Tanggal Penerimaan: 8 Mei 2021
}

\begin{abstract}
Abstrak
Lansia sebagai salah satu kelompok rentan Covid-19 memiliki resiko terhadap berlakunya physical distancing. Penelitian ini bertujuan mengetahui bentuk dukungan kelompok meliputi ekonomi, kesehatan, mental, dan sosial dalam menghadapi pandemi covid 19 pada lansia. Jenis penelitian deskriptif kualitatif fenomenologi. Jumlah 13 informan dengan Focus Group Discucssion. Hasil penelitian memberikan dukungan pada lansia selama pandemi covid 19 dengan memberikan paket sembako, saling mendukung satu sama lain, tidak memberikan stigma yang buruk pada masyarakat yang sedang melakukan isolasi mandiri. Meningkatkan peran kelompok dukungan social untuk meningkatkan derajat kesehatan lansia selama pandemic covid 19 menjadi rekomendasi dari penelitian ini.
\end{abstract}

Kata kunci: dukungan; lansia; covid-19

\section{Support The Elderly During The Pandemic Covid-19}

\begin{abstract}
The elderly as one of the vulnerable groups for Covid-19 have a risk of implementing physical distancing. This research aims to know how a group of community giving the support during the pandemic. 13 informans were recruited in Focus Group Discussion. The study explain that Ranting 'Aisyiyah giving support their community especially the elderly during the pandemic including economic, health, psychologic, and sosial support. Support from families, relatives, neighbors and social are needed in order to avoid the stigma of being Covid-19 patien. The study recommend to enhance grup support for the elderly in order to improve health quality.
\end{abstract}

Keywords: support; elderly; covid-19

\section{PENDAHULUAN}

Novel coronavirus (2019-nCoV) menyebabkan pandemi global dalam beberapa bulan menyusul empat kasus pertama yang dilaporkan di Wuhan, China, pada 29 Desember 2019. Lansia dengan komorbid seperti asma, penyakit kardiovaskular 
(CVD), hipertensi, penyakit ginjal kronis (CKD), atau obesitas mengalami risiko lebih tinggi menjadi sakit parah jika terinfeksi virus covid 19 (Singu et al., 2020).

Case fatality rate atau tingkat kematian yang disebabkan oleh COVID-19 di Indonesia adalah sekitar 5,9\%. Case fatality rate adalah presentase jumlah kematian dari seluruh jumlah kasus positif COVID-19 yang sudah terkonfirmasi dan dilaporkan. Merujuk pada data tersebut, tingkat kematian (case fatality rate) berdasarkan kelompok usia adalah sebagai berikut:8 0-5 tahun: 2,3\%; 6-17 tahun: 0,6\%; 18-30 tahun: $0,8 \%$; 31-45 tahun: $2,4 \%$; 46-59 tahun: 8,7\%; >60 tahun: $17,7 \%$. Dari seluruh penderita COVID-19 yang meninggal dunia, $0,9 \%$ berusia 0 5 tahun, $0,6 \%$ berusia $6-17$ tahun, $3 \%$ berusia $18-30$ tahun, $12 \%$ berusia $31-45$ tahun, $39,9 \%$ berusia $46-59$ tahun, dan $43,6 \%$ berusia 60 tahun ke atas. Lansia memiliki resiko kematian paling tinggi khususnya bagi lansia yang memiliki penyakit penyerta. Sedangkan berdasarkan jenis kelamin, $62,2 \%$ penderita yang meninggal akibat COVID-19 adalah laki-laki dan 37,8\% sisanya adalah perempuan (Rohmah, 2020). Kekhawatiran untuk terinfeksi Covid-19 terlebih pada lansia sebagai kelompok rentan yang memiliki penyakit penyerta merupakan satu hal yang sangat berpengaruh terhadap kondisi psikologis mereka (Maggi et al., 2021).

Kematian COVID-19 terutama terjadi pada lansia dan terutama di antara mereka yang memiliki penyakit penyerta seperti penyakit kardiovaskular, penyakit pernapasan, atau diabetes. Namun sayangnya belum banyak yang focus dan perduli terhadap kesehatan lansia dalam masa pandemic covid 19. Padahal fokus pada kesehatan lansia di masa pandemi ini sangat dibutuhkan (Anderson et al., 2020).

Lansia sebagai salah satu kelompok rentan Covid-19 memiliki resiko terhadap berlakunya physical distancing yang diterapkan dalam jangka panjang. Periode lansia merupakan periode kehidupan yang perlu mendapatkan perhatian karena pada periode ini rentan terhadap penyakit. Permasalahan yang sering dihadapi oleh usia lanjut yaitu keterbatasan fisik dan kerentanan terhadap penyakit. Dengan bertambahnya usia akan dapat menyebabkan terjadinya perubahan degeneratif dengan manifestasi beberapa penyakit diantaranya hipertensi, kelainan jantung, penyakit diabetes mellitus, kanker rahim/prostat,osteoporosis dan lain-lain (Puspitasari et al., 2019).

Pandemi Covid-19 dalam kehidupan belum pernah terjadi sebelumnya sehingga menyebabkan kecemasan dan ketakutan. Ketakutan akan kematian, ketakutan terhadap keluarga yang sakit, ketakutan terhadap apa yang akan terjadi nanti dan ketakutan jika mengalami perawatan medis. Dukungan sosial sangat diperlukan untuk kesejahteraan mental dalam menghadapi pandemi ini (WHO, 2020).

Hasil penelitian El-Zoghby S. M., Soltan E. M dan Salama H. M (2020) di Negara Mesir berjudul "Impact of the COVID-19 Pandemic on Mental Health and Social Support among Adult Egyptians" dilakukan terhadap 510 responden didapatkan hasil sebanyak 211 responden $(41,4 \%)$ mengalami dampak yang berat, 174 responden $(34,1 \%)$ mengalami stres karena pekerjaan, 284 responden $(55,7 \%)$ stres karena keuangan, 320 responden $(62,7 \%)$ stres karena dirumah, 275 responden $(53,9 \%)$ mengalami ketakutan, 265 responden $(52 \%)$ perasaan tidak berdaya dan 338 responden $(66,3 \%)$ merasa khawatir. Untuk mengurangi berbagai dampak tersebut terjadi peningkatan dukungan sosial dari teman sebanyak 24,2\%, 207 
responden (40,6\%) dukungan dari anggota keluarga dan 176 responden (34,5\%) dukungan sosial dari orang lain (El-Zoghby.S.M. et al., 2020).

Hasil penelitian Arrosyid menunjukkan bahwa sebagian besar responden lansia mendapat dukungan dukungan dari keluarga tinggi yaitu sebanyak 156 responden $(82,5 \%)$. Lansia yang mendapat dukungan dari keluarga cukup terdapat 33 responden $(17,5 \%)$. Dengan masalah yang bisa terjadi pada lansia selama pandemi covid-19, dan berdasarkan hasil penelitian diharapkan dukungan keluarga menjadi solusi untuk masalah yang terjadi pada lansia dalam menghadapi pandemi covid-19 (Arrosyid, 2020).

Saat ini dukungan sosial sangat diperlukan kepada masyarakat umum, pasien serta tenaga medis dalam situasi pandemi Covid-19 (Antara, 2020). Dukungan sosial berbentuk: (1) appraisal support, memecahkan masalah atau menguraikan stresor (2) tangible support, bantuan nyata menyelesaikan masalah (3) self esteem support, dukungan pandangan diri yang baik tentang dirinya dan (4) belonging support, penerimaan dalam satu bagian atau satu kelompok (Isnawati \& Suharriadi, 2012). Bentuk dukungan yang dibutuhkan oleh kelompok ini perlu untuk diketahui sehingga pendampingan yang diberikan lebih efektif dan efisien. Mitigasi yang tepat sangat diperlukan terlebih pada lansia sebagai upaya pencegahan adanya efek jangka panjang physical distancing dan tekanan kondisi pandemic (Maggi et al., 2021)

Hasil penelitian (Dwi \& Santoso, 2020) yang merupakan hasil review dari 6 artikel yang dipilih menyatakan dukungan sosial sangat diperlukan dalam situasi pandemi Covid-19. Dukungan sosial berkorelasi positif dengan efikasi diri, kualitas tidur dan kesehatan jiwa, sedangkan berkorelasi negatif dengan kecemasan, stres, depresi, tekanan psikologis dan gejala kompulsif seksual. Dukungan sosial sangat penting dalam dimensi psikologis untuk memberikan keyakinan diri, meningkatkan mekanisme koping dan kualitas hidup. Perbedaan dengan penelitian yang sudah dilakukan dengan penelitian sebelumnya adalah penelitian ini tidak hanya menggali aspek psikologis namun juga menggali bentuk dukungan ekonomi, kesehatan, mental dan social pada lansia.

Salah satu kelompok masyarakat yang kurang mendapatkan dukungan social adalah lansia sehingga berpotensi dan rentan mengalami permasalahan kesehatan mental dan fisik selama pandemi COVID-19. Hal tersebut disebabkan karena lanjut usia mengalami kesulitan dalam penyesuaian diri dan asing dengan lingkungan sosialnya. Lansia banyak yang mengalami berbagai masalah gangguan kesehatan, penyakit terbanyak yang diderita lansia adalah hipertensi (57\%), penyakit sendi (40\%), anemia (30\%) dan katarak (15\%) dan penyakit degeneratif lainnya (8\%). Penyakit tersebut merupakan penyebab utama disabilitas lansia.

Lansia merupakan kelompok yang paling rentan dan memiliki resiko paling tinggi dibandingkan yang lainnya, karena adanya perubahan kondisi fisik, sosial dan psikologis, serta penurunan produksi hormon dalam tubuh yang berakibat pada menurunnya fungsi organ-organ di dalam tubuhnya. Lanjut usia juga harus dihadapkan pada masalah di aspek psikologis salah satunya kecemasan. Kurangnya dukungan membuat kecemasan pada lansia meningkat. Selain itu lansia juga mengalami kesulitan dalam penyesuaian diri dengan lingkungan sosialnya, 
sehingga banyak masalah masalah baik kesehatan maupun psikologis yang dihadapi lansia.

Berdasarkan analisis diatas pentingnya menjaga kesehatan lansia selama masa pandemic covid 19 karena dengan covid 19 dapat memperburuk dan menurunkan status derajat kesehatan lansia sehingga dibutuhkan suatau dukungan dari berbagi pihak agar lansia tetap sehat dalam masa pandemic covid 19. Selama Covid 19 kita harus menerapkan physical distanching dalam penelitian (Gloster et al., 2020) menyebutkan bahwa physical distanching atau jaga jarak menghambat akses seseorang untuk mendapatkan perawatan kesehatan dan menyebabkan terbatasanya interaksi social yang dapat berdampak negative pada kesehatan fisik dan mental seseorang khusunya lansia.

Hasil penelitian (Ugbolue et al., 2020) lansia lebih rentan jika komplikasi dari covid 19 berkembang sehingga diperlukan perawatan intensif jika kondisi individu memburuk karena kondisi medis yang kesehatan karena atau penyakit penyerta misalnya serebrovaskular, endokrin, kardiovaskular, pencernaan dan penyakit pernafasan. Sehingga pentingnya menjaga kesehatan dan memberikan dukungan pada lansia selama pandemic covid 19.

Aisyiyah berupaya untuk menurunkan masalah masalah kesehatan baik kesehatan fisik maupun psikologis pada lansia. Aisyiyah melalui Majelis Kesehatan di setiap wilayahnya membuat program-program kesehatan. Program kesehatan yang dilakukan oleh Majelis Kader sangat banyak yaitu pemeriksaan kesehatan, penyuluhan, dll yang dilakukan oleh kader bekerjasama dengan lintas sektoral seperti Puskesmas dan institusi pendidikan. Guna meningkatkan kesehatan masyarakat maka kader berperan aktif untuk membentuk kesadaran masyarakat agar dapat meningkatkan kualitas hidupnya kader dapat menyampaikan informasi kesehatan yang diperolehnya kepada masyarakat.

Tidak semua keluarga tetap menjaga kesehatan saat dirumah saja, terbatasnya ruang gerak karena hanya dirumah perlu menjadi perhatian. Orang tua dan anakanak sedang menghadapi disrupsi kehidupan yang besar akibat wabah penyakit Coronavirus (Covid-19). Penutupan sekolah, physical distancing, banyak hal berat yang harus dilalui dan tentunya ini adalah masa yang sulit bagi seluruh anggota keluarga (KEMENKES, 2020). Penelitian ini bertujuan untuk melihat dukungan pada kelompok ranting 'Aisyiyah dalam menghadapi pandemi covid 19.

\section{METODE}

Penelitian ini menggunakan pendekatan deskriptif kualitatif dengan pendekatan fenomenologi. Pengumpulan data dilakukan dengan Focus Group Discussion (FGD) dan wawancara mendalam pada lansia di Ranting 'Aisyiyah Nogotirto. Penelitian ini bertujuan mendiskripsikan lebih dalam tentang dukungan dalam menghadapi pandemic covid-19. Informan dalam penelitian ini berjumlah 13 meliputi: Ketua Ranting 'Aisyiyah Nogotirto sebanyak 1 informan, Majelis Kesehatan 2 informan, anggota 10 informan. Kriteria dalam pemilihan informan pengasuh dan pengurus antara lain: (1) bersedia dijadikan informan, (2) mengetahui latar belakang dan kondisi Ranting 'Aisyiyah Nogotirto (3) Aktif di kegiatan di Ranting 'Aisyiyah Nogotirto. 
Tahap penelitian dengan pemilihan subjek penelitian yang sesuai dengan kriteria, pengumpulan data melalui FGD, wawancara mendalam dan dokumentasi. Tahap pengujian memverifikasi kealamian data yang diambil dari sumber data primer. Instrumen yang digunakan pedoman wawancara. Teknik wawancara yang digunakan berupa teknik wawancara tidak terstruktur atau wawancara terbuka. Wawancara dilakukan untuk mendapatkan informasi mengenai dukungan yang diperoleh lansia selama masa pandemic covid 19 meliputi dukungan ekonomi berupa bantuan yang diperoleh, dukungan kesehatan upaya menjaga kesehatan selama covid 19, bentuk dukungan psikologis yang dilakukan dan didapatkan dan bentuk bentuk dukungan social yang di dapatkan selama pandemi covid-19 baik dari keluarga maupun masyarakat.

Uji kredibilitas untuk menguji kredibilitas data atau kepercayaan terhadap data hasil penelitian kualitatif antara lain dilakukan dengan perpanjangan pengamatan, peningkatan ketekunan dalam penelitian, triangulasi, diskusi dengan teman sejawat, analisis kasus, dan member check menggunakan teknik triangulasi, yaitu pengecekan data dari berbagai sumber dengan berbagai cara, dan berbagai waktu. Dalam penelitian ini digunakan triangulasi metode dan sumber dengan menggunakan dua modus yaitu membandingkan hasil pengamatan dan data wawancara, serta membandingkan hasil wawancara dengan isi dokumentasi. Penelitian ini sudah mendapatkan surat ijin etika penelitian dari Komite Etik Penelitian Kesehatan Universitas Aisyiyah Yogyakarta dengan nomor 1348/KEPUNISA/X/2020.

\section{HASIL DAN PEMBAHASAN}

\section{A. HASIL}

\section{Dukungan Ekonomi}

Berdasarkan hasil wawancara dengan Majelis Kesehatan Ranting 'Aisyiyah Nogotirto menyampaikan bahwa kegiatan yang dilakukan oleh Ranting 'Aisyiyah Nogotirto beraneka ragam misalnya acara bakti sosial dan pembagian paket sembako. Ranting Aisyiyah Nogotirto selama pandemic covid 19 ini melakukan beberapa program untuk membantu warga yang terdampak covid-19 dalam bentuk paket sembako. Dibawah ini adalah informasi responden mengenai hal tersebut.

"Paket kita bagi untuk warga yang terdampak, misalnya buruh yang jadi nggak bisa kerja karena Covid, jadi nggak ada pemasukan”.'( R2 15/10/2020)

Berdasarkan hasil wawancara dengan responden menyampaikan:

"Selama covid 19 ini penghasilan menurun, sulit untuk memenuhi kebutuhan sehari-hari apalagi".( R2 15/10/2020)

Berdasarkan hasil analisis tersebut sehingga ranting Aisyiyah Nogotirto berinisiatif untuk memberikan paket sembako kepada warga yang terdampak covid 19 termasuk di dalamnya adalah buruh bangunan, tukang becak, penjual keliling dll. Kegiatan pembagian paket sembako dilaksanakan tidak hanya selama Covid-19 namun sudah menjadi program rutin Ranting Aisyiyah Nogotirto.

Berdasarkan hasil wawancara dengan Majelis Kesehatan Ranting 'Aisyiyah Nogotirto menyampaikan bahwa kegiatan yang dilakukan oleh Ranting 'Aisyiyah 
Nogotirto beraneka ragam misalnya bakti sosial yang diselenggarakan oleh Pimpinan Ranting 'Aisyiyah Nogotirto, setiap tahunnya di bulan Ramadan. Selain itu ada pembagian 500 paket sembako murah yang diberikan kepada masyarakat yang membutuhkan yang tersebar di tujuh padukuhan di Nogotirto. Dibawah ini adalah informasi responden mengenai hal tersebut.

"Kegiatan lainnya dalam bentuk Santunan untuk anak yatim piyatu di bulan Mukharom dan juga santunan biaya pendiidkan untuk anak TK-SMA dengan donasi berkisar 100.000-175.000. Donatur berasal dari Pengurus dan Anggota Aisyiyah serta Masyarakat sekitar" (R5 15/10/2020)

Begitu banyak dukungan ekonomi yang telah diberikan oleh ranting aisyiyah pada warga sekitar tidak hanya lansia namun juga menjangkau segala aspek mulai dari anak anak sampai dengan keluarga yang terdampak secara finansial karena covid 19 sehingga dapat membantu masyarakat sekitar dalam hal pemenuhan kebutuhan sehari-hari.

\section{Dukungan Kesehatan}

Ranting 'Aisyiyah Nogotirto sangat aktif melakukan kegiatan dakwah pada masyarakat dalam segala bidang baik kesehatan, pendidikan sosial dll sebelum adanya pandemi Covid-19. Sebelum pandemi Covid-19 kegiatan posyandu lansia sudah rutin berjalan diadakan setiap tanggal 15 setiap bulannya dengan kegiatan rutin pemeriksaan kesehatan dan penyuluhan.

Dalam melaksanakan pemeriksaan kesehatan Ranting 'Aisyiyah Nogotirto bekerjasama dengan tenaga medis yakni perawat dan bidan Universitas 'Aisyiyah Yogyakarta (UNISA) dan dokter dari Fakuktas Kedokteran dan Ilmu Kesehatan (FKIK) Universitas Muhammadiyah Yogyakarta (UMY).Dalam menjalankan programnya kader bekerjasama dengan beberapa lintas sectoral. Berikut penuturan responden mengenai hal tersebut.

"Dalam melaksanakan kegiatan Ranting Aisyiyah Nogotirto bekerjasama dengan UMY, UNISA, RS PKU Muhammadiyah Yogyakarta. Berikut penuturan responden" (R1 15/10/2020)

"Kerjasama dengan UMY, Rumah Sakit Queen Latifa "(R2 15/10/2020)

"Satgas dari UNISA yang memberi edukasi, dikasih materi-materi gitu" (R1/15/10/2020)

Sebelum pandemi juga dilaksanakan pemeriksaan mata pada lansia yang dilakukan di AMC bekerjasama dengan kedokteran UMY. Kegiatan dalam pemeriksaan kesehatan gratis ini berupa konsultasi, pemeriksaan kesehatan, tekanan darah, kolestrol, gula darah, asam urat dan pemberian obat bagi yang memerlukan. Dibawah ini adalah informasi yang disampaikan oleh responden.

"Pemeriksaan dalam bentuk pemeriksaan Tekanan Darah, Gula Darah, Kolesterol, dan Konsultasi medis. " (R5 15/10/2020)

Kader Kesehatan di PRA Aisyiyah Nogotirto mampu berperan dengan baik dalam mengkoordinir dan menggerakkan masyarakat untuk mengikuti semua kegiatan, sehingga masyarakat menjadi antusias. Dibawah ini adalah penuturan responden.

"Semua program yang mengkoordinir adalah kader kesehatan dan alhamdulillah sampai saat ini tidak ada kendala. Kader juga yang menggerakkan 
masyarakat agar ikut berpartisipasi dalam semua kegiatan dan masyarakat antusias dengan kegiatan yang di ikuti (R2 15/10/2020)

Kegiatan kegiatan yang dilakukan pada lansia ini sebagai bentuk dukungan yang dilakukan oleh kader kesehatan ranting Aisyiyah Nogotirto sebagai upaya mewujudkan lansia yang sehat. Namun kegiatan ini berhenti selama Covid-19.

Program kesehatan selama pandemi Covid-19 tidak berjalan karena himbauan untuk melakukan physical distancing sehingga tidak memungkinkan mengadakan kegiatan untuk mengumpulkan anggota dalam jumlah yang banyak. Kegiatan keagamaan tetap bisa berjalan melalui zoom setiap minggunya. Masyarakat berharap ada kegiatan kesehatan yang bisa dilakukan secara online dan juga media yang bisa dimanfaatkan untuk mengakses informasi selama masa pandemi Covid-19 ini. Masyarakat berharap bisa mengadakan kegiatan yang rutin seperti dulu sehingga bisa melakukan monitoring kesehatan seperti sebelum Covid-19. Dibawah ini adalah penuturan responden mengenai hal tersebut.

"Selama pandemic covid -19 ini pengajian dan pemeriksaan kesehatan tidak berjalan" (R4 15/10/2020)

Selama pandemi Covid-19 kader di Ranting 'Aisyiyah Nogotirto belum pernah mengadakan kegiatan yang berhubungan dengan kesehatan dengan tatap muka langsung. Selama Covid-19 ini kegiatan yang berhubungan dengan kesehatan berhenti sehingga tidak ada pemeriksaan kesehatan dan juga penyuluhan kesehatan yang dilakukan secara tatap muka. Dukungan kesehatan yang selama ini sudah dilakukan oleh ranting asyiyah yang di gerakkan oleh Kader kesehatan berupa penyuluhan kesehatan dengan menggunakan zoom.

Kader Ranting 'Aisyiyah Nogotirto selalu memberikan semangat dan motivasi agar para lansia melakukan aktivitas fisik setiap harinya untuk dapat selalu meningkatkan derajat kesehatannya. Paruntu et al., dalam studinya melaporkan bahwa terdapat hubungan antara aktivitas fisik dengan hipertensi, semakin sering sesorang melakukan aktivitas fisik maka akan semakin kecil risiko terkena penyakit hipertensi (Paruntu et al., 2015). Aktifitas fisik juga dapat meningkatkan kekebalan tubuh seseorang. Untuk peningkatan kesehatan tubuh, aktifitas fisik/olahraga dilakukan 3 sampai 5 kali dalam seminggu dan dilakukan secara teratur (Amran et al., 2012). Kurangnya aktivitas fisik/olahraga ini juga di alami oleh responden. Mereka menyampaikan olahraga 1-2 x/minggu saja biasanya saat ahad pagi senam bersama dengan ibu-ibu komplek perumahan.

\section{Dukungan Mental/Psikologis}

Selama Covid-19 ini mereka berusaha untuk tetap sabar, saling mendoakan baik untuk diri sendiri, keluarga dan sesama muslim. Dibawah ini adalah penuturan responden mengenai hal tersebut.

"Sabar" (R1 15/10/2020)

"Berdoa dan mendoakan sesama Muslim” (R2 15/10/2020)

"Berdoa" (R3 15/10/2020)

"Menerapak protocol kesehatan, tidak terlalu cemas takut imunnya ambrol" (R6 15/10/2020)

"Tidak Stres" (R8 15/10/2020) 
Bersabar, berdoa dan menerapkan protocol kesehatan adalah ikhtiar terbaik manusia untuk tetap menjaga kesehatan selama pandemic covid-19. Saling mendoakan sesama muslim dapat memperkuat hubungan sesama manusia sehingga mampu meningkatkan kesehatan mental karena merasa banyak yang mendoakan, banyak yang memberikan dukungan sehingga para lansia lebih semangat dalam menjalani kehidupan selama pandemic covid-19. Dukungan sosial memiliki peranan penting untuk mencegah dari ancaman kesehatan mental.

Berbeda dengan responden lain mengatakan bahwa cemas khawatir terhadap covid -19 ini karena kedua anaknya bekerja sebagai dokter sehingga takut jika anaknya terkena covid 19. Berikut penuturan responden:

"kedua anak saya dokter sehingga agak takut jika mereka terkena covid 19" (R9 15/10/2020)

Karena pandemic covid 19 ini mewajibkan kita untuk menerapkah physical distancing hal ini membuat adaptasi tersendiri bagi para warga khususnya lansia karena mereka biasanya sering berkumpul melakukan kegiatan namun karena wajib menjaga jarak sehingga kegiatan terhenti. Hal ini membuat lansia mengalami kecemasan karena biasanya melakukan pengajian bersama, senam lansia bersama, dan arisan bersama namun saat ini menjadi tidak bisa bertemu. Berikut penuturan responden mengenai hal tersebut:

"Kangen pengen pengajian bareng, olahraga bareng, sekarang tidak ada kegiatan jadi sepi" (R1 15/10/2020)

"Dirumah cuma berdua dengan suami, karena diminta untuk dirumah saja sehingga tidak pernah ada kegiatan diluar" (R1 15/10/2020)

Dari informasi responden tersebut lansia menginginkan kegiatan bersama seperti sebelum pandemic covid 19 sehingga bisa olahraga senam lansia bersama, pengajian bersama bahkan pemeriksaan kesehatan bersama sama. Lansia menyampaikan bahagia saat bisa bertemu dengan lansia lansia yang lain bisa saling bercerita. Namun saat ini berkomunikasi hanya melalui whatsapp dan rasanya berbeda tidak seperti bertemu langsung.

\section{Dukungan Sosial}

Selama pandemic covid 19 ini masyarakat yang ada di wilayah Ranting Aisyiyah saling mendukung. Dukungan diberikan melalui grup WA dengan memberikan dukungan informasi kesehatan tentang covid-19. Selama masa pandemic covid-19 ini beberapa media yang digunakan warga untuk mengakses informasi dengan menggunakan Grup WA dll. Berikut penuturan responden.

"Upaya edukasi yang dilakukan adalah jika ada informasi dari Muhammadiyah kemudian di share ke anggota melalui Grup WhatUp " (R1 15/10/2020).

Selain WA media lain yang efektif yang digunakan oleh masyarakat adalah youtube. Berikut penuturan responden.

"Melihat youtube selain dapat informasi juga olahraga mengikuti gerakan di youtube" (R8 15/10/2020)

Sumber-sumber dukungan sosial berasal dari orang tua, saudara kandung, anak-anak, kerabat, pasangan hidup atau suami/istri, teman bekerja dan juga dari tetangga. Saat pandemic corona virus ini saatnya untuk saling 
mendukung. Dukungan sosial sangat penting dalam setiap proses penting dan krisis dalam kehidupan, banyak orang menarik diri karena tidak mengetahui tentang apa yang harus dikatakan dan perbuat serta bagaimana agar dapat membantu orang lain. Dukungan social yang di dapatkan responden dalam bentuk memberikan perhatian lebih kepada keluarga. Berikut penuturan responden mengenai hal tersebut.

"Di dalam lingkungan keluarga saling mendukung selama masa covid-19 ini dengan memberikan perhatian lebih terutama jika anak tiba tiba harus isolasi mandiri setelah melakukan test swab kepada pasien yang ternyata positif. Dukungan juga dilakukan dengan membantu menjaga cucu agar mereka bisa bekerja dengan tenang" (R1 15/10/2020)

"Jika anak sedang isolasi mandiri hanya berada dirumah saja dan respon masyarakat biasa biasa saja” (R1 15/10/2020)

Dukungan sosial sangat efektif untuk mengatasi tekanan psikologis pada keadaan sulit dan tertekan. Sebagai contoh yaitu dukungan sosial untuk membantu memperkuat fungsi imunitas tubuh, menekan respons fisiologis terhadap stres serta memperkuat fungsi untuk merespons terhadap penyakit (Dwi \& Santoso, 2020).

\section{B. PEMBAHASAN}

\section{Dukungan Ekonomi}

Berdasarkan hasil wawancara dengan Majelis Kesehatan Ranting 'Aisyiyah Nogotirto menyampaikan bahwa kegiatan yang dilakukan oleh Ranting 'Aisyiyah dalam rangka memberikan dukungan kepada warga yang ada di wilayah ranting adalah dengan memberikan bantuan paket sembako. Hal ini dilakukan bekerjasama dengan aparatur wilayah setempat seperti Ketua Rukun Tetangga (RT) dalam hal pendataan warga yang terdampak Covid-19 dari sisi ekonomi. Paket sembako diberikan bagi warga yang terdampak, misalnya buruh yang jadi nggak bisa kerja karena Covid sehingga tidak ada pemasukan.

Sebelum pandemi covid 19 ranting Aisyiyah rutin mengadakan pembagian paket sembako yang biasanya di adakan pada bulan Ramadhan dan Alhamdulillah pada bulan Ramadhan kemarin tetap bisa membagikan paket sembako ke warga dengan menerapkan protokol kesehatan dan langsung dibagikan ke rumah rumah warga.

Berdasarkan hasil wawancara dengan responden yang menyatakan bahwa saat pandemi covid 19 membuat semakin sulit untuk memenuhi kebutuhan hidup sehari - hari. Bahkan beberapa warga menyampaikan ada beberapa yang di berhentikan dari tempat bekerjanya misalnya sebagai buruh pabrik dll. Hal ini sejalan dengan hasil penelitian (Ugbolue et al., 2020) Secara global wabah pandemi COVID-19 telah memicu kelesuan ekonomi dan meningkatnya pengangguran. Akibatnya, masyarakat global harus menghadapi stresor terkait fisik, kesehatan, psikologis dan sosial ekonomi.

Berdasarkan hasil wawancara responden menyampaikan bahwa ada rasa kekhawatiran dalam hal pemenuhan kebutuhan sehari hari karena pendapatan yang menurun. Hal ini sejalan dengan penelitian (Moore \& Lucas, 2021) dari hasil penelitian di dapatkan hasil bahwa terdapat kekhawatiran responden selama 
pandemic covid 19 ini meliputi jika terjadi penularan COVID-19, kekhawatiran status keuangan sehingga berdampak pada ekonomi dan dapat meningkatkan tekanan psikologis responden. Selain itu, responden khawatir tentang keuangan mereka misalnya merasa berhutang jika sampai melakukan isolasi mandiri ini semua berkontribusi pada tekanan psikologis responden.

Sejalan dengan penelitian (Gloster et al., 2020) covid 19 berdampak secara ekonomi yaitu mengakibatkan beberap orang kehilangan pekerjaan dan pendapatan karena harus melakukan physical distancing dan juga isolasi mandiri dan hal ini merupakan fakor resiko yang memperburuk kesehatan mental yang dapat berdampak pada stress, depresi sehingga dibutuhkan suatu dukungan social yang mampu memberikan dampak positif pada kesehatan mental.

\section{Dukungan Kesehatan}

Dalam melaksanakan pemeriksaan kesehatan Ranting 'Aisyiyah Nogotirto selama ini bekerjasama dengan tenaga medis yakni perawat dan bidan Universitas 'Aisyiyah Yogyakarta (UNISA) dan dokter dari Fakuktas Kedokteran dan Ilmu Kesehatan (FKIK) Universitas Muhammadiyah Yogyakarta (UMY). Kegiatan atau program kesehatan yang mengkoordinir adalah kader kesehatan dan berjalan dengan lancar tidak ada kendala. Kader menggerakkan masyarakat agar ikut berpartisipasi dalam semua kegiatan dan warga antusias dengan pelaksanaan kegiatan yang diadakan oleh majelis kesehatan.

Sejak pandemic Covid-19, dukungan kesehatan yang dilakukan berkordinasi dengan UNISA serta RS Queen Latifa dalam proses pemberian edukasi protokol pencegahan penularan Covid-19 serta proses rujukan bagi warga yang membutuhkan pemeriksaan. Selain itu sejak menuculnya covid-19 di Indonesia, UNISA merespon cepat dengan kondisi tersebut yaitu dengan dibentuknya satgas UNISA. Selama masa pandemic Covid 19 satgas UNISA aktif memberikan memberi edukasi dan memberi materi kesehatan kepada masyarakat sekitar UNISA.

Kader berperan sebagai koordinator, penggerak masyarakat, pemberi pertolongan dasar. Kader mampu meningkatkan kualitas hidup masyarakat. Peran kader kesehatan penting untuk menciptakan kondisi agar masyarakat dapat meningkatkan kesehatan bagi masyarakat itu sendiri, keluarga dan masyarakat sekitar, sebagai anggota masyarakat yang dipercaya dan memahami kesehatan (Sulaeman, 2012). Salah satu bentuk peran kader di Aisyiyah adalah menjadi pelopor gerakan hidup sehat, menjadi pengurus Ranting 'Aisyiyah dan dapat menyampaikan informasi kesehatan yang diperolehnya kepada masyarakat. Kader juga bertanggung jawab dalam pelaksanaan program (Hidayati \& Mahmudah, 2020).

Dalam menjalankan programnya kader bekerjasama dengan beberapa lintas sectoral. Ranting Aisyiyah Nogotirto bekerjasama dengan UMY, UNISA, RS PKU Muhammadiyah Yogyakarta dan Rumah Sakit Queen Latifa. Konsep pemberdayaan kader seharusnya melibatkan kerjasama lintas sektoral untuk menciptakan kolaboratif yang baik. Kerja sama lintas sektoral ini dilakukan untuk keberlanjutan program kader dalam hal apresiasi yang diberikan. Pentingnya dukungan organisasi dalam pelaksaanaan potensi kader (Rahmawati \& Bajorek, 2013). 
Berbagai penelitian menunjukkan bahwa kader mampu meningkatkan efektifitas pelaksanaan program kesehatan di masyarakat. Hal utama yang harus diperhatikan dalam penugasan kader adalah pendampingan bersifat bukan tindakan invasif, melainkan bersifat promotif yang dapat mencegah faktor risiko dari penyakit. Kader sebagai tenaga lini pertama sebelum dokter dan perawat. Keterlibatan kader menjadi salah satu inovasi yang membantu tenaga kesehatan untuk mencegah komplikasi (Istifada \& Rekawati, 2019).

Dalam melaksanakan kegiatan berjalan dengan baik dan masyarakat antusias mengikuti program program yang diadakan oleh majelis kesehatan karena selain banyak manfaatnya juga program diadakan secara gratis. Namun selama pandemic ini kegiatan kesehatan dalam bentuk tatap muka belum bisa berjalan. Hasil penelitian (Ugbolue et al., 2020) menunjukkan bahwa dari hasil kusioner menunjukkan bahwa terdapat dampak fisik dan psikologis yang dihasilkan dari Pandemi covid 19. Hasil penelitian ini juga menunjukkan tekanan individu yang disebabkan oleh COVID-19 dan konsekuensi kesehatan terkait bagi komunitas global.

Sesuai dengan hasil penelitian ini bahwa mayoritas respon lansia memiliki beberapa penyakit komorbid seperti hipertensi, jantung, diabetes mellitus dll. Sehingga resiko komplikasi akan semakin buruk jika mereka terkena covid-19. Responden menyadari akan hal itu sehingga berdasarkan hasil wawancara mereka menerapkan protocol kesehatan agar terhindar dari covid 19. Responden juga menyampaikan bahwa mereka rutin mengkonsumsi obat obatan dari dokter agar mereka tetap sehat selama pandemic ini. Meskipun mereka takut ke rumah sakit namun mereka membeli obat di apotek dengan copy resep dokter. Hasil ini sesuai dengan hasil penelitian bahwa lansia memiliki tingkat kondisi kesehatan kronis yang yang lebih buruk mislanya dengan hipertensi, diabetes, penyakit arteri koroner, dan penyakit ginjal kronis. Kondisi ini membuat lansia memiliki risiko tertinggi untuk mengalami komplikasi infeksi dan kematian COVID-19 dibandingkan dengan orang yang lebih muda. Pandemi COVID-19 terus menjadi perhatian publik yang mengancam kesehatan bagi negara-negara di seluruh dunia. Sehingga dibutuhkan upaya pencegahan dan pemahaman lengkap tentang semua aspek virus corona untuk mencegah atau mengurangi dampak dari virus corona (Pollard et al., 2020). Lansia dalam masa pandemic covid 19 ini membutuhkan perawatan sangat intensif dan mungkin lebih banyak bergantung pada keluarga dan teman (Anderson et al., 2020).

Dari hasil wawancara juga di dapatkan keterangan bahwa selama corona ini kegiatan lansia adalah menemani cucu sekolah dari rumah, membantu mengerjakan tugas sekolah bagi yang sudah sekolah dan mengasuh cucu yang masih kecil karena daycare tutup. Hal ini diakui membuat lelah tersendiri bagi para lansia dan menjadi tugas tambahan untuk mereka. Hal ini jika berlarut akan menjadi beban tambahan bagi lansia, kelelahan yang berlebihan dapat menggangu kesehatan pada lansia. Lansia menyampaikan setiap hari merasa lelah dan kadang kurang enak badan karena pekerjaan dirumah yang banyak. Namun seakan akan hal ini dianggap biasa biasa saja dan sudah menjadi hal yang wajar. Hal ini sesuai dengan penelitian bahwa anak-anak yang menghabiskan waktu bersama di luar sekolah atau dirumah dapat menimbulkan risiko bagi orang tua ketika kakek-nenek 
untuk sementara merawat cucu mereka saat orang tua sedang bekerja. Efek buruk pada lansia juga dapat terjadi karena perbatasan dengan mengurangi tenaga kerja pengasuh di day care (Anderson et al., 2020).

\section{Dukungan Mental/Psikologis}

Program kesehatan selama pandemi Covid-19 tidak berjalan karena himbauan untuk melakukan physical distancing sehingga tidak memungkinkan mengadakan kegiatan untuk mengumpulkan anggota dalam jumlah yang banyak. Kegiatan keagamaan tetap bisa berjalan melalui zoom setiap minggunya. Masyarakat berharap ada kegiatan kesehatan yang bisa dilakukan secara online dan juga media yang bisa dimanfaatkan untuk mengakses informasi selama masa pandemi Covid19 ini. Mekanisme Coping atau proses penyelesaian terhadap masalah yang ada yang dilakukan oleh Ranting 'Aisyiyah Nogotirto dalam kategori baik. Selama Covid-19 ini mereka berusaha untuk tetap sabar, saling mendoakan baik untuk diri sendiri, keluarga dan sesama muslim. Berusaha sebaik mungkin dalam menerapkan protokol kesehatan, tidak terlalu cemas untuk menjaga imunitas supaya tetap baik.

Tekanan-tekanan psikologis yang ditimbulkan oleh pengalaman social menyebabkan individu berusaha melindunginya dengan koping stress. Secara psikologis koping stres akan memberikan efek pada kekuatan, reaksi emosi, tingkat depresi atau kecemasan serta keseimbangan antara perasaan yang negatif dan positif. Dukungan sosial dapat meningkatkan cara individu dalam menghadapi atau memecahkan suatu masalah yang terfokus pada pengurangan reaksi stres melalui perhatian, informasi serta umpan balik yang diperlukan untuk melakukan koping stress. Dukungan sosial memiliki peranan penting untuk mencegah dari ancaman kesehatan mental. Seorang individu yang memiliki dukungan sosial yang lebih kecil akan lebih memungkinkan mengalami konsekuensi ancaman psikis yang negatif. Keuntungan individu yang memperoleh dukungan sosial yang tinggi akan menjadikan individu menjadi lebih optimis dalam menghadapi kehidupan sekarang dan masa yang akan datang. Dukungan sosial sangat efektif untuk mengatasi tekanan psikologis pada keadaan sulit dan tertekan. Sebagai contoh yaitu dukungan sosial untuk membantu memperkuat fungsi imunitas tubuh, menekan respons fisiologis terhadap stres serta memperkuat fungsi untuk merespons terhadap penyakit (Dwi \& Santoso, 2020).

Dari hasil penelitian ini di dapatkan hasil analisis bahwa dengan adanya physical distancing sehingga membuat para lansia tidak bisa mengadakan kegiatan bersama seperti olahraga bersama, pengajian bersama, arisan bersama. Saat bertemu secara langsung mereka menyampaikan bahagia karena bisa bercerita satu dengan yang lainnya, karena saat ini semua kegiatan terhenti sehingga mereka merasa kesepian. Hal ini sesuai dengan penelitian (Ferraz et al., 2021) Pandemi covid 19 dapat menyebabkan terganggunya kesehatan mental. Jaga jarak atau physical distancing dapat menyebabkan berkurangnya interaksi social sehingga dapat menyebabkan kecemasan, depresi, gangguan stress. Dukungan fisik, psikilogis, spiritual dan komunitas harus selalu dilakukan untuk meningkatkan kesehatan mental. 
Hasil penelitian (Gloster et al., 2020) orang yang meninggalkan rumah tiga kali/minggu atau lebih memberikan pengaruh yang positif daripada mereka yang jarang keluar rumah dan memiliki rasa normalitas yang tinggi. Dari hasil penelitian di dapatkan bahwa para lansia selama pembatasan skala besar ini menyampaikan hanya tinggal irumah saja tidak pernah pergi kemana mana sehiangga ada rasa kesepian dengan kondisi saat ini.

Hasil penelitian (Ugbolue et al., 2020) dampak fisiologis, emosi psikologis dan faktor kesehatan dapat berperan dalam meningkatkan tingkat kecemasan, kesepian dan isolasi sosial selama penguncian/isolasi. Isolasi social dimana tidak adanya koneksi social dapat menyebabkan kesepian sebagai salah satu prediktor penyakit kardiovaskular, penurunan kognitif, peningkatan depresi dan kematian namun hal tersebut masih dianggap sebelah mata dan belum mendapatkan perhatian khusus untuk para lansia.

Berdasarkan hasil wawancara dengan responden juga menyampaikan bahwa mereka mengalami kecemasan selama pandemic covid 19 ini. Mereka takut jika tertular, takut juga karena anak anak menjadi dokter yang bertemu dengan pasien setiap harinya. Namun mereka menyampaikan untuk tidak stress dan selalu berdoa kepada Allah untuk memohon perlindungan dari bahaya covid 19.

Hal ini sesuai dengan penelitian (Ugbolue et al., 2020) Hasil penelitian yang dilakukan dengan mensurvei publik tentang masalah yang terkait dampak psikologis COVID-19 terhadap kesehatan mental. Beberapa studi penelitian dari berbagai negara menunjukkan bahwa tingkat tekanan psikologis bervariasi lintas negara. Spanyol melaporkan $72 \%$ responden survei mereka mengalami peningkatan tekanan psikologis. Australia melaporkan bahwa $78 \%$ responden melaporkan bahwa kesehatan mental mereka menurun sejak wabah, bahkan 25,9\% dilaporkan sangat atau sangat khawatir tertular COVID-19, dan 52,7\% khawatir tentang keluarga dan teman yang tertular COVID-19. India melaporkan bahwa selama COVID-19 pandemi 25\%, 28\%, dan 11,6\% menunjukkan gejala depresi sedang hingga sangat berat, kecemasan dan stres, masing-masing. Meksiko melaporkan 50,3\% tekanan psikologis sebagai sedang hingga parah. China melaporkan dalam survei cross-sectional dari 52.730 peserta yang dilakukan antara 31 Januari dan 10 Februari 2020 dimana 29,3\% responden mengalami ringan hingga sedang distres psikologis, dan 5,1\% mengalami distres berat. Dalam survei lain terhadap 1210 anggota, Wang dkk. melaporkan bahwa 53,8\% peserta menilai dampak psikologis dari COVID-19 wabah sedang hingga berat, 75\% khawatir anggota keluarga mereka tertular COVID-19, dan tingkat depresi sedang hingga berat, kecemasan dan stres masing-masing adalah 16,5\%, 28,8\%, dan 8,1\%. Dari hasil penelitian di berbagai negara dapat disimpulkan bahwa pandemi COVID-19 berdampak pada kesehatan mental, fisik, dan kesejahteraan individu. Hasil statistik menunjukkan tekanan psikologis yang meningkat di masyarakat umum dan negara-negara pada umumnya.

Dari hasil penelitian di dapatkan beberapa factor penyebab kecemasan selama pandemic covid 19 meliputi ketakutan jika terkena dan tertular covid 19 apalagi mereka adalah lansia yang memiliki beberapa komorbid seperti hipertensi, diabetes mellitus, jantung, dll. Hal ini juga di khawatirkan lansia dalam penelitian ini dimana mayoritas lansia memiliki komorbid. Ketakutan selanjutnya terkait 
dengan pemenuhan kebutuhan selama pandemic covid 19 ini karena pendapatan menurun karena beberapa responden merupakan pedagang. Jika mereka terkena covid 19 maka harus isolasi selama 10-14 hari dan selama itu mereka tidak bisa bekerja sehingga mereka khawatir dengan pemenuhan kebutuhan sehari-hari dan mereka takut jika terkena covid 19 mendapat stigma negatif dari masyarakat. Itulah beberapa kekhawatiran para lansia selama masa pandemic covid 19. Kemampuan untuk menghadapi rasa takut terinfeksi covid 19, penyakit penyerta, serta ketidaktahuan dan ketidakpastian tentang pandemi dapat menyebabkan gangguan kondisi psikologis yang dapat disebut dengan phobia corona.

Hal ini sejalan dengan penelitian (Chen et al., 2020) hasil penelitian menunjukkan efek dari lima jenis stresor selama pandemi COVID-19 pada psikologis kesejahteraan: (1) stres terkait penyakit yang mencakup paparan risiko terhadap COVID-19 dan akses ke perawatan medis; (2) persediaan yang tidak memadai kebutuhan hidup; (3) kerugian ekonomi aktual dan yang diantisipasi karena: pandemi; (4) perhatian yang berlebihan pada informasi terkait COVID19; dan ( 5) diskriminasi yang dirasakan.

Dibutuhkan dukungan yang adekuat dapat menjadi jembatan pencegah depresi yang berpengaruh pada kondisi fisik tentunya. Informasi yang jelas terhadap kondisi pandemi serta apa yang harus dilakukan selama masa pandemic merupakan hal yang dapat diberikan untuk penurunan rasa tertekan pada situasi yang tidak pasti. Pemantauan kesehatan tidak boleh lepas dari perhatian, terlebih bagi lansia dengan kondisi penyakit penyerta yang memiliki komorbid.

Sejalan dengan penelitian (Gloster et al., 2020) Selama lockdown meningkatkan stres bagi kebanyakan orang, $11 \%$ melaporkan tingkat stres tertinggi. Gejala depresi juga tinggi, sebanyak 33\% melaporkan tingkat kebosanan yang tinggi, dan hampir 50\% menunjukkan bahwa mereka membuang banyak waktu. Tidak hanya tingkat kesehatan mental yang rendah juga diikuti dengan tingkat kesejahteraan emosional, psikologis, dan sosial yang rendah serta kehilangan produktivitas.

\section{Dukungan Sosial}

Dukungan sosial memiliki peranan penting untuk mencegah dari ancaman kesehatan mental. Seorang individu yang memiliki dukungan sosial yang lebih kecil akan lebih memungkinkan mengalami konsekuensi ancaman psikis yang negatif. Keuntungan individu yang memperoleh dukungan sosial yang tinggi akan menjadikan individu menjadi lebih optimis dalam menghadapi kehidupan sekarang dan masa yang akan datang. Dukungan sosial sangat efektif untuk mengatasi tekanan psikologis pada keadaan sulit dan tertekan. Sebagai contoh yaitu dukungan sosial untuk membantu memperkuat fungsi imunitas tubuh, menekan respons fisiologis terhadap stres serta memperkuat fungsi untuk merespons terhadap penyakit (Dwi \& Santoso, 2020).

Sumber-sumber dukungan sosial berasal dari orang tua, saudara kandung, anak-anak, kerabat, pasangan hidup atau suami/istri, teman bekerja dan juga dari tetangga. Saat pandemi corona virus ini saatnya untuk saling mendukung. Dukungan sosial sangat penting dalam setiap proses pentingdan krisis dalam kehidupan, banyak orang menarik diri karena tidak mengetahui tentang apa 
yang harus dikatakan dan perbuat serta bagaimana agar dapat membantu orang lain. Dukungan social yang dilakukan dalam lingkungan keluarga saling mendukung selama masa covid-19 ini dengan memberikan perhatian lebih terutama jika anak tiba tiba harus isolasi mandiri setelah melakukan pemeriksaan kepada pasien yang ternyata positif.

Pernyataan tersebut sesuai dengan hasil penelitan (Dwi \& Santoso, 2020), dimana bentuk-bentuk dukungan sosial saat pandemi Covid-19 saat ini adalah:(1) appraisal support untuk memecahkan masalah atau menguraikan stress salah satunya adalah menjadi pendengar yang baik, (2) tangible support, berupa bantuan nyata menyelesaikan masalah, bantuan dapat berupa makanan, masker atau peralatan medis yang dibutuhkan,(3) selfes teem support dalam bentuk dukungan mental,dan (4) belonging support berupa penerimaan dalam satu bagian atau satu kelompok, berupa tidak terjadi isolasi social terhadap pasien Covid-19 dan tenaga medis yang merawat pasien Covid-19. Hal ini dibuktkan bahwa jika terdapat salah satu warga yang sedang isolasi mandiri hanya berada dirumah saja dan alhamdulillah respon masyarakat biasa tanpa memberikan stigma negative.

Dukungan sosial dalam menghadapi situasi pandemi corona virus saat ini sangat penting dalam dimensi kesehatan manusia. Dukungan sosial berasal dari keluarga dekat, teman, teman kerja, tetangga dan teman dalam aktivitas kegiatan. Kontak sosial sebenarnya sangat penting bagi kesehatan fisik dan mental. Penelitian menunjukkan bahwa kontak dan dukungan sosial dapat membantu mengurangi stres, depresi, kegelisahan dan isolasi, serta meningkatkan harga diri, kehidupan normal, kesejahteraan dan kualitas hidup, sementara kurangnya dukungan sosial memiliki efek sebaliknya. Efek positif dari dukungan sosial yang baik dapat dijelaskan bahwa dukungan tersebut memiliki dampak langsung pada kesehatan dan kesejahteraan karena memberikan kenyamanan, merasa memiliki tujuan hidup dan keamanan. Dukungan sosial dapat menurunkan berbagai bentuk stres, meningkatkan mekanisme koping dan meningkatkan kualitas hidup (Dwi \& Santoso, 2020) Selama masa pandemic covid-19 ini beberapa media yang digunakan warga untuk mengakses informasi dengan menggunakan Grup WA dll. Muhammadiyah dan Aisyiyah berupaya memberikan edukasi dengan memberikan informasi dari Pimpinan Pusat untuk bisa di turunkan ke cabang dan rating dan sampai dengan masyarakat.

Grup WA menjadi salah satu media efektif dalam menyebarkan informasi. Hal ini sejalan dengan penelitian Rohmah Banyak negara menerapkan lockdown untuk menekan penyebaran virus corona. Media sosial seperti Whatsapp dan Instagram banyak digunakan untuk berkomunikasi. Penggunaan media sosial seperti WhatsApp dan Instagram mengalami lonjakan hingga 40\% selama pandemi virus corona (Rohmah, 2020). Selain Whatsapp, Yotube menjadi platform media social yang digunakan oleh para masyarakat. Masyarakat memanfaatkan youtube selain untuk mendapatkan informasi mengenai covid 19 juga digunakan sebagai media olahraga dengan mengikuti gerakan senam yang ada di youtube.

Hal ini sejalan dengan penelitian Hootsuite menyebutkan bahwa platform media sosial yang paling aktif digunakan adalah Youtube. Youtube menjadi platform yang paling banyak digunakan netizen (sebutan untuk masyarakat di 
media online) sebanyak $88 \%$, Whatsapp merupakan aplikasi chat sebanyak $83 \%$, disusul Facebook sebanyak 81\%, Instagram sebanyak $80 \%$ dan Twitter 52\% (Rohmah, 2020).

Dari hasil penelitian menunjukkan bahwa $80 \%$ nitizen menyetujui bahwa media sosial bermanfaat sebagai sosial informasi. Sebanyak 93\% menyetujui media sosial sebagai media informasi Covid 19 bahkan $85 \%$ menyetujui media sosial dapat memuaskan dalam pencarian informasi Covid $19.80 \%$ nitizen menyetujui bahwa media sosial mampu memuaskan sebagai pelarian dari rutinitas dan masalah pribadi di masa Covid $19.83 \%$ nitizen menyetujui bahwa informasi di media sosial memuaskan dalam membantu sesama (Rohmah, 2020).

Media sosial juga sebagai sebagai pendidikan layanan kesehatan masyarakat. Situs web memberikan berita mengenai Covid-19 secara langsung dan terpercaya dalam memasarkan layanan informasi seperti layanan dana sosial perawatan kesehatan dan postingan yang berkaitan dengan Covid-19 sebagai media yang dapat mampu mengedukasi masyarakat mengenai berbagai ulasan dan testimoni pasien yang sembuh dari Covid-19 sebagai bentuk motivasi dan berbagai upaya pencegahan dan memberikan dukungan antar warga negara Indonesia dalam menghadapi pandemi Covid 19 (Sampurno et al., 2020).

Hasil penelitian ini responden merasakan dukungan social yang diberikan oleh sesama keluarga, saudara dan tetangga memberikan dampak positif. Dukungan social yang diberikan dengan cara menanyakan kabar melalui whatsapp, saling bervideo call. Hal ini sesuai dengan penelitian (Chen et al., 2020) hasil penelitian menunjukkan covid 19 menyebabkan masalah kesehatan yang parah dan memberikan dampak psikologis yang luar biasa pada masyarakat. Berbagai stresor terkait COVID-19, akses perawatan medis terbatas, persediaan dasar yang tidak memadai, pendapatan berkurang, paparan berlebihan terhadap informasi terkait Covid-19, dan diskriminasi yang dirasakan, dikaitkan dengan tekanan psikologis. Dukungan sosial lingkungan dapat mengurangi tekanan psikologis dan menyangga efek stresor terkait Covid-19, sedangkan dukungan dari teman/kerabat memengaruhi koping stres secara terbatas. Sejalan dengan penelitian (Gloster et al., 2020) dukungan social mampu meningkatkan kesehatan mental yang di dapatkan dari keluarga.

\section{SIMPULAN}

Dukungan pada lansia sangat diperlukan dalam situasi pandemi Covid-19 baik dukungan ekonomi, kesehatan, psikologis dan juga social. Dukungan yang diberikan pada lansia dapat meningkatkan derajat kesehatan lansia, membantu perekonomian lansia, menjaga kesehatan mental lansia dengan mengurangi stres dan kegelisan selama masa pandemi covid-19. Perlunya optimalisasi peran dukungan social yang untuk meningkatkan kesehatan lansia sehingga lansia dapat survive selama masa pandemic covid-19 untuk mewujudkan lansia yang sehat baik fisik maupun psikologis. Kader kesehatan tetap berinovasi untuk mengadakan kegiatan yang mampu memberikan dukungan baik fisik maupun non fisik pada lansia. 


\section{DAFTAR PUSTAKA}

Amran, Y., Kusumawardani, R., \& Supriyatiningsih, N. (2012). Determinan Asupan Makanan Usia Lanjut. Kesmas: National Public Health Journal, 6(6), 255. https://doi.org/10.21109/kesmas.v6i6.78

Anderson, M., McKee, M., \& Mossialos, E. (2020). Covid-19 exposes weaknesses in European response to outbreaks. The BMJ, 368(April), 19-21. https://doi.org/10.1136/bmj.m1075

Antara. (2020). Psikolog bagikan cara beri dukungan selama pandemi covid-19. Https://Www.Antaranews.Com/Berita/1455688/Psikolog-Bagikan-Cara-Beri-

Dukungan-Sosial-Saat-Pandemi-Covid-19.

https://www.antaranews.com/berita/1455688/psikolog-bagikan-cara-beri-dukungansosial-saat-pandemi-covid-19

Arrosyid, M. N. (2020). Identifikasi Dukungan Keluarga Dalam Menghadapi Pandemi Covid-19 Pada Lansia Di Wilayah Rw 04 Kelurahan Sambikerep Surabaya. http://repository.um-surabaya.ac.id/4922/\%0A\%0A

Chen, X., Zou, Y., \& Gao, H. (2020). Since January 2020 Elsevier has created a COVID19 resource centre with free information in English and Mandarin on the novel coronavirus COVID- 19. The COVID-19 resource centre is hosted on Elsevier Connect, the company's public news and information. January.

Dwi, M., \& Santoso, Y. (2020). Review Article: Dukungan Sosial Dalam Situasi Pandemi Covid-19. Jurnal Litbang Sukowati, 5(1), 11-26. https://doi.org/10.32630/sukowati.v5i1.184

El-Zoghby.S.M., Soltan.E.M, \& Salama.H.M. (2020). Impact of the COVID-19 Pandemic on Mental Health and Social Support among Adult Egyptians. Journal of Community Health (2020), 45, 689-695. ttps://doi.org/10.1007/s10900-020-00853-5.

Ferraz, D., Dourado, I., Zucchi, E. M., Mabire, X., Magno, L., Grangeiro, A. D., Couto, M. T., Ferguson, L., Westin, M., Alves Dos Santos, L., \& Préau, M. (2021). Effects of the COVID-19 pandemic on the sexual and mental health of adolescent and adult men who have sex with men and transgender women participating in two PrEP cohort studies in Brazil: COBra study protocol. BMJ Open, 11(4). https://doi.org/10.1136/bmjopen-2020-045258

Gloster, A. T., Lamnisos, D., Lubenko, J., Presti, G., Squatrito, V., Constantinou, M., Nicolaou, C., Papacostas, S., Aydın, G., Chong, Y. Y., Chien, W. T., Cheng, H. Y., Ruiz, F. J., Garcia-Martin, M. B., Obando-Posada, D. P., Segura-Vargas, M. A., Vasiliou, V. S., McHugh, L., Höfer, S., ... Karekla, M. (2020). Impact of COVID-19 pandemic on mental health: An international study. PLoS ONE, 15 (12 December), 120. https://doi.org/10.1371/journal.pone.0244809

Hidayati, R. W., \& Mahmudah, N. (2020). Peran kader Ranting 'Aisyiyah Cabang Kota Yogyakarta dalam pemberdayaan masyarakat di bidang kesehatan. Jurnal Kebidanan, 9(1), 15. https://doi.org/10.26714/jk.9.1.2020.15-22

Isnawati, D., \& Suharriadi, F. (2012). Hubungan antara dukungan dosial dengan penyesuaian diri masa persiapan pensiun pada karyawan PT Pupuk Kaltim. Psikologi Industri Dan Organisasi, 1(3), 2-7.

Yekti Satriyandari, Fitria Siswi Utami (Dukungan Pada Lansia Dalam Menghadapi Pandemi....) 
Istifada, R., \& Rekawati, E. (2019). Peran Kader Kesehatan dalam Promosi Pencegahan Komplikasi Hipertensi di Wilayah Perkotaan: Literatur Review. Dunia Keperawatan, 7(1), 28-46.

KEMENKES. (2020). Cegah Virus Corona, Jaga Kesehatan dengan GERMAS. Retrieved April 20, 2020, from http://promkes.kemkes.go.id/cegah-virus-corona-jagakesehatan-dengan-germas.

Maggi, G., Baldassarre, I., Barbaro, A., Cavallo, N. D., Cropano, M., Nappo, R., \& Santangelo, G. (2021). Mental health status of Italian elderly subjects during and after quarantine for the COVID-19 pandemic: a cross-sectional and longitudinal study. Psychogeriatrics, 21(4), 540-551. https://doi.org/10.1111/psyg.12703

Moore, K. A., \& Lucas, J. J. (2021). COVID-19 distress and worries: The role of attitudes, social support, and positive coping during social isolation. Psychology and Psychotherapy: Theory, Research and Practice, 94(2), 365-370. https://doi.org/10.1111/papt.12308

Paruntu, O. L., Fisik, H. A., Gizi, S., Hipertensi, D. A. N., Paruntu, O. L., Rumagit, F. A., Kures, S., Manado, J., \& Tomohon, D. K. (2015). Hubungan Aktivitas Fisik, Status Gizi Dan Hipertensi Pada Pegawai Di Wilayah Kecamatan Tomohon Utara. GIZIDO, $7(1)$.

Pollard, C. A., Morran, M. P., \& Nestor-Kalinoski, A. L. (2020). The covid-19 pandemic: A global health crisis. Physiological Genomics, 52(11), 549-557. https://doi.org/10.1152/physiolgenomics.00089.2020

Puspitasari, P., Rinata, E., \& Salim, A. (2019). Peningkatan Derajat Kesehatan Masyarakat Melalui Pemeriksaan Kesehatan dan Edukasi Pola Hidup Sehat. JPM (Jurnal Pemberdayaan Masyarakat), 4(1), 376-382. https://doi.org/10.21067/jpm.v4i1.3258

Rahmawati, R., \& Bajorek, B. (2013). Preventing Chronic Disease A Community Health Worker-Based Program for Elderly People With Hypertension in Indonesia: A Qualitative Study, 2013. Prev Chronic Dis, 12(140530), 1-9. http://dx.doi.org/10.5888/

Rohmah, N. N. (2020). Media Sosial Sebagai Media Alternatif Manfaat dan Pemuas Kebutuhan Informasi Masa Pandemik Global Covid 19 (Kajian Analisis Teori Uses And Gratification). Al-I'lam: Jurnal Komunikasi Dan Penyiaran Islam, 4(1), 1-16. https://journal.ummat.ac.id/index.php/jail/article/view/2957/1905

Sampurno, M. B. T., Kusumandyoko, T. C., \& Islam, M. A. (2020). Budaya Media Sosial, Edukasi Masyarakat, dan Pandemi COVID-19. SALAM: Jurnal Sosial Dan Budaya Syar-I, 7(5). https://doi.org/10.15408/sjsbs.v7i5.15210

Singu, S., Acharya, A., Challagundla, K., \& Byrareddy, S. N. (2020). Impact of Social Determinants of Health on the Emerging COVID-19 Pandemic in the United States. Frontiers in Public Health, 8(July), 1-10. https://doi.org/10.3389/fpubh.2020.00406

Sulaeman, E. S. (2012). Model pemberdayaan masyarakat bidang kesehatan: Studi Program Desa Siaga. Title. National Public Health Journal, 7 (4), 186-192.

Ugbolue, U., Duclos, M., Urzeala, C., Berthon, M., Kulik, K., Bota, A., Thivel, D., Bagheri, R., Gu, Y., Baker, J., Andant, N., Pereira, B., Rouffiac, K., Clinchamps, M., \& Dutheil, F. (2020). An Assessment of the Novel COVISTRESS Questionnaire: 
COVID-19 Impact on Physical Activity, Sedentary Action and Psychological Emotion. Journal of Clinical Medicine, 9(10), 3352. https://doi.org/10.3390/jcm9103352

WHO. (2020). Statement on the second meeting of the International Health Regulations (2005) Emergency Committee regarding the outbreak of novel coronavirus (2019$n C o V)$. https://www.who.int/news-room/detail/30-01-2020-statement-on-thesecond-meeting-of-the-international-health-regulations-(2005)-emergencycommittee-regarding-the-outbreak-of-novel-coronavirus-(2019-ncov). 